\author{
๑๐. О. Колеснік ${ }^{1}$ А. І. Рибін ${ }^{2}$ \\ ${ }^{1}$ Національний інститут раку, Київ \\ ${ }^{2}$ Одесъкий національний медичний університет, Одеса
}

\title{
ПРОГНОЗУВАННЯ ЕФЕКТИВНОСТІ ЛІКУВАННЯ ХВОРИХ НА РАК ЯЕЧНИКІВ
}

Мета дослідження - вивчення медико-біологічних основ прогнозування ефрективності платинової хіміотерапії та підвищення чутливості пухлини до хіміотерапії першої лінії.

Матеріали та методи. 32007 до 2011 року було обстежено 189 пацієнток з аденокарциномою яєчників III-IV стадії, яким після субоптимальної або неоптимальної циторедуктивної операції у післяопераційному періоді були проведені курси ад'ювантної хіміотерапії препаратами платини. Критерієм розподілу на групи була чутливість пухлини до препаратів платини.

Результати дослідження та їх обговорення. Показано, що для пацієнток з РЯ є характерним напруження саногенетичних механізмів організму. Стан саногенезу в організмі пацієнток, хворих на рак яєчників, впливає на чутливість або рефррактерність пухлини до хіміотерапії препаратами платини. До маркерів прогнозу платинорезистентності відносяться генетична обтяженість (наявність мутантних алелів поліморфізмів BRCA1 5832insC та BRCA2 6174delAG у гетеро- та гомозиготному варіантах, мікросателітної нестабільності), висока активність циклінів D та E, підвищення рівнів катехоламінів, високий ступінь експресії оксиду азоту, ступінь гіперурикемії, активність експресії рецепторів до епідермального фрактора росту та активність СAS 20q13. У жінок з наявністю вказаних фракторів доцільно застосовувати медикаментозну корекцію дисрегуляційних порушень.

Висновок. При ймовірній платинорезистентності доцільно на фоні стандартної терапії першої лінії застосовувати медикаментозну корекцію дисрегуляційних порушень (донатори оксиду азоту, детоксиканти, антиурикемічні засоби). При прогнозованій платиночутливості стандартна терапія першої лінії може бути доповнена засобами, які покращують переносимість терапії, але використання медикаментозної корекції дисрегуляційних порушень є недоцільним.

Ключові слова: рак яєчників; лікування; платинорезистентність; прогнозування; платина; дисрегуляційні порушення; саногенез.

\section{ПРОГНОЗИРОВАНИЕ ЭФФЕКТИВНОСТИ ЛЕЧЕНИЯ БОЛЬНЫХ РАКОМ ЯИЧНИКОВ}

Цель исследования - изучение медико-биологических основ прогнозирования эффективности платиновой химиотерапии и повышение чувствительности опухоли к химиотерапии первой линии.

Материалы и методы. C 2007 по 2011 год было обследовано 189 пациенток с аденокарциномой яичников III-IV стадии, которым после субоптимальный или неоптимальной циторедуктивной операции в послеоперационном периоде были проведены курсы адъювантной химиотерапии препаратами платины. Критерием деления на группы была чувствительность опухоли к препаратам платины.

Результаты исследования и их обсуждение. Показано, что для пациенток с Ря характерно напряжение саногенетических механизмов организма. Состояние саногенеза в организме пациенток, больных раком яичников, влияет на чувствительность или ресрактерность опухоли к химиотерапии препаратами платины. К маркерам прогноза платинорезистентности относятся генетическая отягощенность (наличие мутантных аллелей полиморфизмов BRCA1 5832insC и BRCA2 6174delAG в гетеро- и гомозиготном вариантах, микросателлитной нестабильности), высокая активность циклинов $\mathrm{D}$ и E, повышение уровня катехоламинов, высокая степень экспрессии оксида азота, степень гиперурикемии, активность экспрессии рецепторов эпидермального фрактора роста и активность CAS 20q13. У женщин с наличием указанных факторов целесообразно применять медикаментозную коррекцию дисрегуляционных нарушений.

Выводы. При вероятной платинорезистентности целесообразно на фроне стандартной терапии первой линии применять медикаментозную коррекцию дисрегуляционных нарушений (донаторы оксида азота, детоксиканты, антиурикемические средства). При прогнозируемой платиночувствительности стандартная терапия первой линии может быть дополнена средствами, которые улучшают переносимость терапии, но использование медикаментозной коррекции дисрегуляционных нарушений нецелесообразно.

Ключевые слова: рак яичников; лечение; платинорезистентность; прогнозирование; платина; дисрегуляционные нарушения; саногенез.

\section{PREDICTION OF TREATMENT EFFICIENCY IN PATIENTS WITH THE OVARIAN CANCER}

The aim of study - to learn biomedical bases of predicting the effectiveness of platinum chemotherapy and increase the sensitivity of tumors to first-line chemotherapy.

Materials and Methods. From 2007 to 2011189 patients with ovarian adenocarcinoma III-IV stage were examined. They underwent adjuvant chemotherapy courses with drugs platinum after suboptimal or suboptimal cytoreductive surgery in postoperative period. The criterion for the dividing into groups was sensitivity to platinum drugs.

Results and Discussion. It was shown that women with ovarian cancer have typical tension of sanogenetic mechanisms in human body. State of sanogenesis in patients with ovarian cancer affects the sensitivity or refractority of tumors to chemotherapy with platinum drugs. To the markers of platinum-resistance we should include the genetic ones (presence of mutions in BRCA1 5832insC and BRCA2 6174delAG in hetero- and homozygous variant, microsatellite instability), high activity of cyclins D and E, increased levels of catecholamines, high level expression of nitric oxide, the degree hyperuricemia, active expression receptors for epidermal growth factor and activity CAS 20q13. Women with the presence of these factors need to apply appropriate drugs for correction of disregulator violations. 
Conclusions. If probable platinumresistance is advisable due to the standard first-line therapy they should use the drugs for correction of disregulator disorders (donors of nitric oxide, detoxicant, anti-uricemic remedies). In patients with predictable sensitivity to platinum standard first-line treatment can be supplemented by remedies that can improve the tolerated therapy, but it is inappropriate to use the medicines for correction of disregulator disorders.

Key words: ovarian cancer; treatment; resistance to platinum; prognosis; platinum; disregulator violations; sanogenesis.

ВСТУП. За показниками смертності рак яєчників (РЯ) випереджає рак тіла матки та рак шийки матки, посідаючи 5-те місце серед причин смерті від усіх пухлин у жінок та 7-ме місце за частотою захворюваності [1, 2, 9, 12, 13]. В Європі, Великобританії, а також у Північній Америці стандартизовані показники захворюваності на РЯ найбільш високі (10 та більше на 100 тис.). У Центральній та Південній Америці, Афрриці, Азії та в Японії ці показники значно нижче (7 і менше на 100 тис.). За останні роки рівні захворюваності на РЯ в більшості країн з високим ризиком (Скандинавія, Великобританія, США, Канада) залишаються стабільними та навіть дещо знижуються $[9,13,18]$. Водночас відзначається зростання захворюваності в країнах з низьким ризиком, таких, як Японія, Індія, Сінгапур, а також в деяких країнах Південної і Східної Європи. При цьому в 2015 році в Україні захворюваність склала 16,5 на 100 тис. населення, а смертність - 9,1 на 100 тис. населення. Причому на частку I-ІІ стадій припадає тільки 35,4 \% хворих, що були виявлені вперше, а поширені форми складають 64,6 \% спостережень. Показник захворюваності досягає найбільшого значення у віці 60-74 років - 36,9 \%. Середній вік для всіх захворювань - 58,7 року. Приріст захворюваності в Україні за останні 15 років склав 6,2 \% (з 10,3 у 2000 році, 15,6 у 2007 році до 16,5 у 2015 році) [11, 12]. РЯ - досить часте захворювання і тому непогано охарактеризований у відношенні різних молекулярно-генетичних аномалій. Слід зазначити, що пошкодження онкогенів та антионкогенів, які бувають при РЯ, мають достатньо неспецифрічний характер і спостерігаються у багатьох інших пухлинах епітеліального походження [14, 17]. Основною проблемою діагностики та лікування РЯ залишається відсутність скринінгу та, виходячи з цього, пізня діагностика. У 70-80 \% випадків Ря діагностується на III-IV стадії, коли вже неможливо виконати оптимальну циторедуктивну операцію, тому всі надії лікарів покладаються на ад'ювантну хіміотерапію, де на першому етапі застосовуються препарати платини [6, 9, $12,19]$. Незважаючи на те, що РЯ належить до найбільш чутливих до хіміотерапії пухлин, приблизно у 30-40 \% хворих вже ссрормована або може виникати на фоні лікування резистентність до препаратів платини $[3,15,16$, 18]. Такі пухлини називають платинорезистентними (якщо прогресування захворювання має місце протягом 6 місяців після лікування) та платинорефрактерними (якщо прогресування хвороби має місце під час проведення лікування) Незважаючи на те, що сьогодні у порівнянні з 2000-ми роками значно збільшилась кількість фракторів, які дозволяють припустити, якою буде відповідь на лікування при РЯ і якими можуть бути віддалені результати (наприклад мутації генів BRCA 1, BRCA 2, MLH, MSH, активність фрактора росту ендотелію судин та його рецептора, сурвініну, р53 та ін.), інформаційна цінність цих фракторів залишається дуже низькою та багато з них потребують подальшого вивчення [5, 8-10, 15]. Ми вважаємо, що цей фракт пов'язаний перш за все з дуже великою акцентуацією дослідників на генетичних фракторах прогнозу і недостатнім розумінням ролі так званого «генетичного скринінгу» та «генетичного ризику» формування й розвитку того чи іншого явища, в тому числі і на фроні онкологічного захворювання в організмі людини $[4,6,7,18]$. 3 іншого боку, багато невдач у дослідженні фракторів прогнозу платинорезистентності у хворих на серозний РЯ пов'язано з досить поверхневим вивченням фундаментальних медико-біологічних основ цього процесу як на мікрорівні, так і на макрорівні та відсутністю досліджень кореляції цих явищ. Виходячи з цього, слід зазначити, що на сьогодні як в Україні, так і в усьому світі не існує комплексного підходу до прогнозування й підвищення чутливості РЯ до хіміотерапії першої лінії (платинової хіміотерапії), що обумовлює актуальність розробки і застосування такого підходу у пацієнток з РЯ після виконання їм оптимальної циторедуктивної операції.

МЕТА ДОСЛІДЖЕННЯ - вивчення медико-біологічних основ прогнозування ефективності платинової хіміотерапії та підвищення чутливості пухлини до хіміотерапії першої лінії.

МАТЕРІАЛИ ТА МЕТОДИ. 32007 до 2011 року на базі Одеського обласного онкологічного диспансеру було обстежено 189 пацієнток з аденокарциномою яєчників III-IV стадії, яким після субоптимальної або неоптимальної циторедуктивної операції у післяопераційному періоді були проведені курси (6 курсів) ад'ювантної хіміотерапії

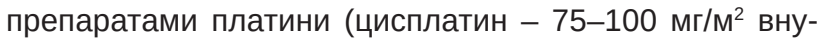
трішньовенно краплинно з гідратацією й фрорсованим діурезом кожних 3 тижні). Критерієм розподілу на групи була чутливість пухлини до препаратів платини. Для аналізу були відібрані хворі з поширеними пухлинами (III, IV стадій), оскільки хворі з I-II стадіями мають у цілому сприятливий прогноз, а головним прогностичним фрактором $€$ адекватність хірургічного стадіювання.

Першу групу (n=59) становили пацієнтки з рецидивом захворювання протягом 6 місяців спостереження після закінчення лікування (платинорезистентні пухлини).

До другої групи (n=44) були віднесені хворі з прогресуванням захворювання на фоні проведення платинової хіміотерапії (платинорефррактерні пухлини).

Третю групу ( $n=86)$ становили пацієнтки без рецидиву захворювання протягом 6 місяців спостереження після закінчення лікування (платиночутливі пухлини).

Критеріями реєстрації рецидиву, відповідно до рекомендацій FIGO, були рівні маркерів CA-125, HE4 і дані КТ органів малого таза, черевної порожнини та заочеревинного простору, а також дані об'єктивного огляду пацієнтки (критерії рецидиву раку яєчників за FIGO та У. Т. Крісманом, 2011).

У всіх трьох групах було проведено:

- аналіз клініко-анамнестичних характеристик, факторів ризику розвитку раку яєчників (відповідно до фракторів ризику за FIGO та У. Т. Крісманом, 2011) [10];

- аналіз потенційних фракторів прогнозу платинорезистентності: 1) гістологічний тип пухлини; 2) ступінь диференціювання пухлини; 3) розмір первинної пухлини яєчника; 4) максимальний розмір внутрішньочеревних метастазів 
(по очеревині та у великому сальнику); 5) наявність асциту; 6) наявність метастазів у заочеревинних лімфовузлах або у вісцеральних органах; 7) обсяг операції (оптимальна 3 максимальним розміром резидуальних пухлинних мас до $1 \mathrm{~cm}$, неоптимальна з розміром резидуальних пухлинних мас більше 1 см або експлоративна); 8) ЕССЮ-статус на момент початку хіміотерапії; 9) рівень СА-125 до початку хіміотерапії;

- особливості рецепторного профрілю та стану тканинних регуляторів (ендотеліальний фрактор росту, експресія рецепторів фрактора росту ендотелію судин, циклін $D$, циклін E, епідермальний фрактор росту, експресія рецепторів епідермального срактора росту, р53, сурвінін);

- порівняльний аналіз особливостей хромосомного апарату лімсоцитів периферичної крові хворих (хромосоми лімфоцитів перифреричної крові, фррагільні сайти хромосом периферичної крові);

- порівняльний аналіз генетичних мутацій і поліморфрізму в генах, що можуть бути задіяні у виникненні і розвитку пухлинної патології в яєчниках і формуванні платинорезистентності (BRCA 1 поліморфрізм 185delAG, BRCA 1 поліморфізм 5382insC, BRCA 2 поліморфізм 6174delT, мікросателітна нестабільність, MLH 1, MSH 2);

- порівняльний аналіз маркерів дисрегуляційної патології (загальна й місцева активність оксиду азоту, рівні катехоламінів, рівні сечової кислоти);

- порівняльний аналіз внутрішньоклітинної активності сірки (S) - як антагоніста платини у клітині - у тканині пухлин яєчників.
Порівняльний аналіз отриманих даних був проведений із використанням критерію хі-квадрат, точного критерію Фішера у випадку малих вибірок, критерію Крускала - Уолліса та/або логарифмічного рангового критерію (С. Гланц, 1998). Нульова гіпотеза приймається при значенні р<0,05. Криві тривалості життя і значень сурогатної перемінної створювалися за методом Каплана - Майера. Вплив чинників ризику на виживання оцінювали за допомогою регресійного аналізу за Коксом. Статистичний аналіз даних проведений із використанням програм Microsoft Excel; Statistica software release 10.0 (Dell StatSoft Inc); SPSS software release 17.0 (SPSS Inc), MedCalc 4.1.

РЕЗУЛЬТАТИ ДОСЛІДЖЕННЯ ТА ЇХ ОБГОВОРЕННЯ. Проведений аналіз отриманих нами даних показав, що у пацієнток із подібними клініко-анамнестичними характеристиками первинна резистентність до препаратів платини $€$ детермінованою декількома чинниками. У таблиці 1 представлені результати регресійного й односракторного дисперсійного аналізу щодо взаємозв'язку між показниками гомеостазу, окремими маркерами прогнозу та загальними характеристиками у хворих на РЯ із збереженою чутливістю до цисплатину. 3 неї можна бачити, що ані вік, ані особливості спадкового та репродуктивного анамнезу, ані наявність професійних шкідливостей практично не впливають на платиночутливість.

Можна припустити, що дисрегуляційні порушення $€$ однією з найважливіших ланок, що обумовлює низьку чутливість пацієнток з РЯ до сполук платини. У цілому, на сьо-

Таблиця 1. Результати аналізу впливу різних чинників ризику на рівень платиночутливості (при відсутності пухлинної прогресії)

\begin{tabular}{|l|c|c|c|c|}
\hline \multirow{2}{*}{ Фактори впливу } & \multicolumn{3}{c|}{ Критерії } \\
\cline { 2 - 5 } & $\mathrm{r}$ & $\mathrm{B}_{\mathrm{xy}}$ & $\eta^{2}$ & $\mathrm{~F}$ \\
\hline Вік & 0,28 & 0,155 & 0,13 & 2,1 \\
\hline Обтяжений спадковий анамнез & 0,31 & 0,142 & 0,14 & 2,2 \\
\hline Безплідність & 0,30 & 0,094 & 0,11 & 2,0 \\
\hline Просесійні шкідливості & 0,32 & 0,097 & 0,12 & 2,1 \\
\hline Ступінь дисеренціювання & $-0,58$ & 0,321 & 0,29 & 3,7 \\
\hline Розміри первинної пухлини & $-0,56$ & 0,290 & 0,26 & 3,5 \\
\hline Наявність асциту & $-0,55$ & 0,307 & 0,27 & 3,6 \\
\hline Максимальний розмір внутрішньочеревних метастазів & $-0,63$ & 0,319 & 0,30 & 3,7 \\
\hline Наявність метастазів у заочеревинних лімсовузлах або у & $-0,51$ & 0,268 & 0,16 & 2,4 \\
\hline вісцеральних органах & & & & \\
\hline Неоптимальна циторедуктивна операція & $-0,54$ & 0,293 & 0,17 & 2,7 \\
\hline ЕСGО-статус & $-0,42$ & 0,175 & 0,21 & 2,2 \\
\hline ВRСА1 & $-0,44$ & 0,175 & 0,22 & 2,3 \\
\hline ВRСА2 & $-0,36$ & 0,311 & 0,23 & 2,3 \\
\hline МСН & 0,40 & 0,160 & 0,20 & 1,9 \\
\hline Циклін Е & $-0,43$ & 0,180 & 0,22 & 2,1 \\
\hline Циклін D & 0,40 & 0,160 & 0,20 & 2,9 \\
\hline КА & 0,42 & 0,220 & 0,17 & 2,2 \\
\hline NO & $-0,54$ & 0,290 & 0,24 & 3,0 \\
\hline Сечова кислота & $-0,58$ & 0,336 & 0,26 & 3,6 \\
\hline ЕFR & $-0,44$ & 0,410 & 0,32 & 2,5 \\
\hline САS20q13 & $-0,50$ & 0,250 & 0,22 & 2,9 \\
\hline S & $-0,24$ & 0,058 & 0,14 & 2,2 \\
\hline
\end{tabular}

Примітка. r - коесріцієнт кореляції, $\mathrm{B}_{\text {ху }}$ - коесріцієнт детермінації, $\eta^{2}$ - інтенсивність впливу R на досліджувані чинники, F - фрактичний критерій Фішера. 
годні уважається, що дисрегуляція - це загальнобіологічна категорія: вона може виникати в усіх живих системах і на всіх структурно-срункціональних рівнях складного організму, охоплювати різні процеси, органи й системи. У тяжких випадках, наприклад при онкологічних захворюваннях, дисрегуляційна патологія може набути значення хвороби регуляції. Природа й механізми саногенетичних процесів залежать від патогенетичної структури патологічних процесів, тобто від того, які органи й системи охоплені патологічним процесом. Вважається, що саногенез індукується патогенезом і починається з моменту впливу патологічного чинника на організм. У нормальних умовах саногенетичні процеси не проявляються, їхню роль виконують захисні адаптаційні механізми. Якщо ж останні виявляються недостатніми, виникає патологічний процес, що активує споконвічно закладені, але не активні саногенетичні процеси й індукує виникнення нових саногенетичних механізмів відповідно до особливостей патологічного процесу, який розвивається. Як і патологічний процес, саногенетичні механізми можуть бути локальними й загальними. Стосовно платинорезистентності у хворих на РЯ ми вважаємо більш цікавими для дослідження місцеві саногенетичні механізми, що мають місце у тканині яєчників при виникненні й розвитку в ньому пухлинної патології. Відповідно до загальноприйнятої думки, сьогодні загальним недоліком багатьох досліджень є те, що вони визначають кількісну сторону змін (підвищення або зниження вмісту тих чи інших біологічно активних речовин, числа рецепторів, рівня гормонів), але не визначають біо- логічне значення цих показників. Аналіз будь-якого процесу, особливо пухлинного, у плані дисрегуляційної патології вимагає розуміння біологічної значимості виявлюваних змін: $€$ вони патогенетичними чи вони саногенетичні. Багато хто з експериментаторів і клініцисти мають справу, власне кажучи, із дисрегуляційною патологією, іноді навіть не підозрюючи про це. Між тим знання дисрегуляційних механізмів і розуміння їх біологічного значення забезпечують правильний підхід до вивчення патологічних процесів і розробки їх патогенетичної терапії.

Це підтверджується результатами кореляційного та дисперсійного аналізу (табл. 2).

При проведенні фракторного аналізу (табл. 3) впливу різних протеомічних та генетичних маркерів на ступінь платинорезистентності встановлено існування двох прихованих фракторів, для першого з яких найбільше значення мають показники активності циклінів $D(f=0,73)$ та $E(f=0,84)$, a також наявність фрункціональних поліморфізмів BRCA1 5832insC $(\mathfrak{f}=0,82)$ та BRCA2 6174delAG $(\mathfrak{f}=0,75)$, мікросателітної нестабільності $(f=0,84)$, так само як й активність катехоламінів (для адреналіну $-\mathrm{f}=0,84$, а для катехоламіну - $f=0,82)$ та ступінь експресії NO in situ $(f=0,73)$. Крім того, у складі даного фрактора міститься ступінь гіперурикемії $(\mathfrak{f}=0,75)$ та внутрішньоклітинний вміст сірки $(\mathfrak{f}=0,68)$.

Натомість другий фрактор утворений переважно експресією рецепторів до епідермального фрактора росту $(\mathfrak{f}=0,71)$ та активністю CAS $20 q 13(\mathfrak{f}=0,71)$. Крім того, певне значення мають такі показники, як $\mathrm{mm} 23-\mathrm{HI}(\mathrm{f}=0,69)$ та

Таблиця 2. Результати аналізу впливу різних чинників ризику на рівень платинорезистентності (при наявності пухлинної прогресії)

\begin{tabular}{|c|c|c|c|c|}
\hline \multirow{2}{*}{ Фактори впливу } & \multicolumn{4}{|c|}{ Критерії } \\
\hline & $r$ & $\mathrm{~B}_{\mathrm{xy}}$ & $\eta^{2}$ & $\mathrm{~F}$ \\
\hline Вік & 0,33 & 0,162 & 0,15 & 2,3 \\
\hline Обтяжений спадковий анамнез & 0,37 & 0,156 & 0,14 & 2,2 \\
\hline Безплідність & 0,32 & 0,107 & 0,12 & 2,1 \\
\hline Професійні шкідливості & 0,34 & 0,101 & 0,12 & 2,1 \\
\hline Ступінь диференціювання & 0,66 & 0,442 & 0,36 & 4,1 \\
\hline Розміри первинної пухлини & 0,63 & 0,290 & 0,26 & 3,5 \\
\hline Наявність асциту & 0,57 & 0,315 & 0,29 & 3,8 \\
\hline Максимальний розмір внутрішньочеревних метастазів & 0,65 & 0,319 & 0,30 & 3,5 \\
\hline $\begin{array}{l}\text { Наявність метастазів у заочеревинних лімфовузлах або у } \\
\text { вісцеральних органах }\end{array}$ & 0,66 & 0,333 & 0,33 & 3,4 \\
\hline Неоптимальна циторедуктивна операція & 0,61 & 0,307 & 0,26 & 2,9 \\
\hline ECGO-статус & 0,58 & 0,283 & 0,25 & 2,9 \\
\hline BRCA1 & 0,58 & 0,285 & 0,24 & 2,8 \\
\hline BRCA2 & 0,53 & 0,275 & 0,22 & 2,6 \\
\hline $\mathrm{MCH}$ & 0,52 & 0,238 & 0,22 & 2,5 \\
\hline Циклін Е & 0,66 & 0,180 & 0,22 & 2,5 \\
\hline Циклін D & 0,65 & 0,160 & 0,20 & 2,9 \\
\hline KA & 0,73 & 0,456 & 0,37 & 3,8 \\
\hline NO & 0,72 & 0,445 & 0,36 & 3,7 \\
\hline Сечова кислота & 0,69 & 0,384 & 0,34 & 3,7 \\
\hline EFR & 0,65 & 0,422 & 0,33 & 3,5 \\
\hline CAS20q13 & 0,58 & 0,347 & 0,31 & 3,3 \\
\hline $\mathrm{S}$ & 0,64 & 0,296 & 0,30 & 3,4 \\
\hline
\end{tabular}

Примітка. $r$ - коесріцієнт кореляції, $B_{\text {ху }}$ - коефіцієнт детермінації, $\eta^{2}$ - інтенсивність впливу R на досліджувані чинники, F - фрактичний критерій Фішера. 
Акушерство та гінекологія

Таблиця 3. Результати факторного аналізу ролі різних протеомічних та генетичних факторів

\begin{tabular}{|c|c|c|}
\hline Показники & Factor - 1 & Factor - 2 \\
\hline VEGF & $-0,29$ & 0,09 \\
\hline EGF & 0,20 & 0,45 \\
\hline Циклін D & 0,73 & 0,41 \\
\hline Циклін Е & 0,84 & $-0,33$ \\
\hline REGF & 0,24 & 0,71 \\
\hline HER2 & 0,41 & 0,16 \\
\hline $\mathrm{Bcl}-2$ & $-0,19$ & 0,70 \\
\hline p53 & 0,003 & 0,66 \\
\hline Сурвінін & $-0,25$ & $-0,009$ \\
\hline FS & $-0,12$ & $-0,16$ \\
\hline BRCA1 185delAG & 0,42 & 0,54 \\
\hline BRCA1 5832insC & 0,82 & 0,51 \\
\hline BRCA2 6174delAG & 0,75 & 0,44 \\
\hline MLH1 & $-0,07$ & 0,52 \\
\hline $\mathrm{MSH} 2$ & 0,84 & $-0,33$ \\
\hline CAS 20q13 & 0,24 & 0,71 \\
\hline TP53 & 0,41 & 0,16 \\
\hline $\mathrm{nm} 23-\mathrm{HI}$ & $-0,19$ & 0,69 \\
\hline RB2/p130 & 0,003 & 0,66 \\
\hline $\mathrm{NO}_{3 \mathrm{ar}}$ & 0,20 & 0,45 \\
\hline $\mathrm{NO}_{\text {місц }}$ & 0,73 & 0,41 \\
\hline Адреналін & 0,84 & $-0,33$ \\
\hline Норадреналін & 0,82 & 0,51 \\
\hline Сечова кислота & 0,75 & 0,44 \\
\hline Внутрішньоклітинна сірка & 0,68 & 0,54 \\
\hline
\end{tabular}

RB2/p130 (f=0,66). Останні є малодоступними для вітчизняних лабораторій, втім при необхідності виконання подібних аналізів у просрільних лікувально-профрілактичних установах може бути швидко налагоджено.

Після проведення обчислень нами одержане рівняння, яке дозволяє більш точно прогнозувати платинорезистентність у пацієнток з РЯ:

\section{$R=0,3 \times T+0.1 \times G+0,1 \times C y c l+0,1 \times K A+0,3 \times N 0+0,1 \times U A+0,1 \times E F R+$ $+0,1 \times \operatorname{CAS} 20 \mathrm{q} 13$,}

де $\mathrm{R}$ - ризик платинорезистентності, при R>1,0 платинорезистентність $€$ ймовірною, при $\mathrm{R}>2,0 €$ ймовірною платинорефрактерність;

Т - відповідність критеріям, сформульованим С. А. Тюландіним, залежно від кількості відповідностей може дорівнювати від 0 до 5 ( $T \in(0-5)$;

$\mathrm{G}$ - наявність мутантних алелів поліморфізмів BRCA1 5832insC та BRCA2 6174delAG у гетеро- та гомозиготному варіантах та/або мікросателітної нестабільності (G $\in(0-5)$;

Cycl - висока активність циклінів D та E (Cycl $\in(0-2))$;

KA - активність катехоламінів (KA $\in(0-1)$;

$\mathrm{NO}$ - вираженість експресії (NO $\in(0-5)$;

$U A-$ ступінь гіперурикемії (UA $\in(0-1)$;

EFR - експресія рецепторів до епідермального фрактора росту $\in(0-5)$;

CAS 20q13 активність CAS 20q13 $\in(0-1)$.

Застосування наведеної формули допомогає розподілити загальний масив пацієнток одразу після первинного контакту залежно від даних клініко-лабораторних та клініко-інструментальних досліджень, у тому числі імуногістохімічних, на декілька груп, в яких ПХТ проводиться диференційовано, із використанням превентивних медикаментозних схем, спрямованих на мінімізацію побічних есректів та токсичної дії препаратів.

ВИСноВКИ. 1. Основними чинниками ризику виникнення раку яєчників $€$ вік старше 50 років $(\mathrm{HR}=2,5)$, куріння (HR=2,0), безплідність (HR=2,2), множинні аборти $(\mathrm{HR}=2,1)$, гіпогалактія $(\mathrm{HR}=1,8)$, анормальні маткові кровотечі в анамнезі $(\mathrm{HR}=1,9)$, гіпертрофний аліментарний статус (HR=2,0), обтяжений спадковий анамнез $(\mathrm{HR}=1,8)$, перенесене онкологічне захворювання (HR=1,7), гіперурикемія $(\mathrm{HR}=2,2)$, ендотеліальна диссункція $(\mathrm{HR}=2,1)$, професійні шкідливості $(\mathrm{HR}=1,6)$. Поширеність цих фракторів у субпопуляціях платиночутливих та платинорезистентних хворих на епітеліальний рак яєчників значущо не відрізняється.

2. Для пацієнток з РЯ є характерним напруження саногенетичних механізмів організму. Стан саногенезу в організмі пацієнток хворих на рак яєчників впливає на чутливість або рефррактерність пухлини до хіміотерапії препаратами платини.

3. До маркерів прогнозу платинорезистентності відносяться такі параметри, як генетична обтяженість (наявність мутантних алелів поліморфізмів BRCA1 5832insC та BRCA2 6174delAG у гетеро- та гомозиготному варіантах, мікросателітної нестабільності), висока активність циклінів D та E, підвищення рівнів катехоламінів, високий ступінь експресії NO, ступінь гіперурикемії, активність експресії рецепторів до епідермального фрактора росту та активність CAS 20q13. 
4. У жінок із наявністю вказаних фракторів доцільно застосовувати медикаментозну корекцію дисрегуляційних порушень. При ймовірній платинорезистентності доцільно на фоні стандартної терапії першої лінії застосовувати медикаментозну корекцію дисрегуляційних порушень (донатори оксиду азоту, детоксиканти, антиурикемічні засоби). При прогнозованій платиночутливості стандартна терапія першої лінії може бути доповнена засобами, які покращують переносимість терапії, але використання медикаментозної корекції дисрегуляційних порушень $€$ недоцільним.

ПЕРСПЕКТИВИ ПОДАЛЬШИХ ДОСЛІДЖЕНЬ. СЛіД зазначити, що подальший пошук патогенетично обґрунтованих маркерів платинорезистентності $€$ одним із найпріоритетніших завдань сучасної онкології, особливо в контексті такої складної патології, як РЯ.

\section{СПИСОК ЛІТЕРАТУРИ}

1. Аксель М. А. Лекции по онкогинекологии / М. А. Аксель, В. В. Баринов, Л. И. Бокина. - М. : МЕДпресс-инорорм, 2009. - 425 C.

2. Бохман Я. В. Лекции по онкогинекологии / Я. В. Бохман. - М. : МИА, 2007. - 304 с.

3. Важенин А. В. Актуальные вопросы клинической онкогинекологии / А. В. Важенин, А. В. Жаров, И. Г. Шимоткина. - М. : СТРОМ, 2010. - 128 с.

4. Генетика пухлин жіночих репродуктивних органів / за ред. В. М. Запорожана. - Одеса : Одес. держ. мед. ун-т, 2004. - 332 c.

5. Генетическая медицина / [В. Н. Запорожан, В. А. Кордюм, Ю. И. Бажора и др.] ; под ред. В. Н. Запорожана. - Одесса : ОНМедУ, 2008. - 432 с.

6. Анализ мутации генов BRCA-1 и BRCA-2 у платинорефрактерных больных раком яичников / В. Г. Дубинина, А. И. Рыбин, О. В. Лукьянчук, О. В. Кузнецова // Вісник морської медицини. - 2013. - № 1. - С. 46-52.

7. Активность белка р53 у больных раком яичников в зависимости от чувствительности к препаратам платины $/$ В. Г. Дубинина, А. И. Рыбин, О. В. Кузнецова, О. Н. Морозюк // Клиническая онкология. - 2015. - № 4. - С. 1-4.

8. Експресія p53, VEGF та CD34 у пухлинній тканині та виживаність хворих на серозний рак яєчника / Л. Г. Бучинська, В. М. Гринкевич, Н.П.Юрченко [та ін.] // Онкологія. - 2009. - T. 11, № 2. - C. 109-112.

9. Клиническая онкогинекология / под ред. В. П. Козаченко. - М. : Медицина, 2005. - 376 с. : ил.

10. Филипп Дж. Дисая. Клиническая онкогинекология : в 3-х т. / Филипп Дж. Дисая, Уильям Т. Крисман. - М. : Практическая медицина, 2011. - 988 с.

\section{REFERENCES}

1. Axel, M.A., Barinov, V.V., \& Bokina, L.I. (2009). Lektsii po onkoginekologii [Lectures on oncogynecology]. Moscow: MEDpressinform [in Russian].

2. Bohman, Ya.V. (2007). Lektsii po onkoginekologii [Lectures on oncogynecology]. Moscow: MIA [in Russian].

3. Vazhenin, A.V., Zharov, A.V., \& Shimotkina, I.G. (2010). Aktualnye voprosy klinicheskoy onkoginekologii [Actual questions of clinical oncogynecology]. Moscow: STROM [in Russian].

4. Zaporozhyan, V.M. (Ed.) (2004). Henetyka pukhlyn zhinochyh reproduktivnykh orhaniv [Genetics of the femalereproductive organs]. Odesa derzh. med. un-t [in Ukrainian].

5. Zaporozhan, V.N., Kordyum, V.A., \& Bazhora, Y. (Ed. Zaporozhyan, V.N.) (2008). Geneticheskaya meditsyna [Genetic medicine]. Odesa: ONMEDU [in Ukrainian].
11. Рак в Україні, 2014-2015. Захворюваність, смертність, показники діяльності онкологічної служби / [3. П. Федоренко, Ю. Й. Михайлович, Л. О. Гулак та ін.] ; гол. ред. О. О. Колеснік. - К., 2016. - № 17. - 144 с.

12. Свинцицкий В. С. Серозный рак яичников: тестирование мутаций генов BRCA1 и BRCA2 в Украине / В. С. Свинцицкий // Евразийский онкологический журнал (приложение). - 2015. - С. 79-82.

13. Урманчеева А. Ф. Практическая онкогинекология: избранные лекции / А. Ф. Урманчеева, С. А. Тюляндина, В. М. Моисеенко. - СПб. : ТОММ, 2008. - 400 с.

14. Химиотерапия злокачественных новообразований / под ред. Э. Чу и В. Т. де Вита (перевод с англ.). - М. : Практика, 2008. - 447 с.

15. Biochemical, cellular and pharmacological aspects of the multidrug transporter / S. V. Ambudakar, S. Dey, C. A. Hrycyna [et al.] // Ann. Rev. Pharmacol. Toxicol. - 1999. - Vol. 39. P. 361-398.

16. Chu G. Cellular responses to cisplatin / G. Chu // J. Biol. Chem. - 2004. - Vol. 2269. - P. 787-790.

17. Hereditary ovarian carcinoma: heterogeneity, molecular genetics, pathology, and management / H. T. Lynch, M. J. Casey, C. L. Snyder [et al.] // Mol. Oncol. - 2009. - Vol. 3. - P. 97-137.

18. Rybin A. I. Personalized managing of the patients with serous ovarian cancer / A. I. Rybin // ESGO Prevention in gynecological malignancies, September 08-10, 2016, Antalya, Turkey. - P. 35

19. Cancer genetics: risks and mechanisms of cancer in women with inherited susceptibility to epithelial ovarian cancer / L. P. Shulman, J. S. Dungan // Cancer Treat. Res. - 2010. Vol. 156. - P. 69-85.

6. Dubinina, V.G., Rybin, A.I., Lukyanchuk, O.V., \& Kuznetsova, O.V. (2013). Analiz mutatsii geniv BRCA-1 i BRCA-2 u platynorefrakternyh patsientok $z$ rakom yaichnikov [Analysis of mutation of BRCA-1 and BRCA-2 genes in platinum-refractory patients with ovarian cancer]. News of Naval Medicine, 1, 4652 [in Russian].

7. Dubinina, V.G., Rybin, A.I., Kuznetsova, O.V., \& Morozyuk, O.N. (2015). Aktivnost belka p53 u bolnykh z rakom yaichnikov v zavisimosti ot chuvstvitelnosti k preparatam platiny. [Activity of p53 protein in patients with ovarian cancer, depending on sensitivity to platinum preparations]. Klinichna onkolohiia Clinical Oncology, 4, 1-4 [in Russian].

8. Buchinska, L.G., Grinkevich, V.M., Yurchenko, N.P. (2009). Ekspressia of p53, VEGF i CD34 v tkani opuholi $i$ vyzhivaemost bolnykh seroznym rakom yaichnikov [Expression of p53, VEGF and CD34 in tumor tissues and survilance of 
patients with the serous ovarian cancer]. Onkolohiia - Oncology, (11), 2, p. 109-112 [in Russian].

9. Kozachenko, V.P. (Ed). (2005). Klinicheskaya onkoginekologia [Clinical oncogynecology]. Moscow: Meditsina [in Russian]. 10. Philip, J., Dysay, \& William, T. Krisman (2011). Klinicheskaya onkoginekologia: $v$ tomakh [Clinical oncogynecology: in 3 volumes]. Moscow: Prakticheskaya meditsyna [in Russian].

11. Kolesnik, O.O. (Ed). Fedorenko, Z.P., Mykhailovych, Yu.Y., Hulak L.O. (2016). Rak v Ukraini, 2014-2015. Zakhvoriuvanist, smertnist, pokaznyki diialnosti onkolohichnoi sluzhby [Cancer in Ukraine, 2014-2015. Morbidity, mortality, the indeces of oncological service activity]. Kyiv [in Ukrainian].

12. Svintsitskyy, V.S. (2015). Seroznyi rak yaichnikov: testirovanie mutatsyy genov BRCA1 and BRCA2 v Ukraini [Serous ovarian cancer: testing of mutations in the BRCA1 and BRCA2 genes in Ukraine]. Eurasian Oncology Journal (attachment), 79-82 [in Russian].

13. Urmancheeva, A.F., Tyulyandina, S.A., \& Moiseenko, V.M. (2008). Prakticheskaya onkoginekologia; izbrannye lektsii [Practical oncogynecology: selected lectures]. St.-Petersburg: "TOMM" [in Russian].
14. Chu, E., \& De Vita, V.T. (Ed.) (2008). Khimioterapia zlokachestvennyh opuholei [Chemotherapy of malignant neoplasms] / (translated from English). Moscow: Practice [in Russian].

15. Ambudakar, S.V., Dey, S., \& Hrycyna, C.A. (1999). Biochemical, cellular and pharmacological aspects of the multidrug transporter. Ann. Rev. Pharmacol. Toxicol. (39), 361-398.

16. Chu, G. (2004). Cellular responses to cisplatin. J. Biol. Chem. (2269), 787-790.

17. Lynch, H.T., Casey, M.J., \& Snyder C.L. (2009). Hereditary ovarian carcinoma: heterogeneity, molecular genetics, pathology, and management. Mol. Oncol. 3, 97-137.

18. Rybin, A. I. (2016). Personalized managing of the patients with serous ovarian cancer. ESGO Prevention in gynecological malignancies, 08-10, Antalya, Turkey. 35 p.

19. Shulman, L.P., \& Dungan, J.S. (2010). Cancer genetics: risks and mechanisms of cancer in women with inherited susceptibility to epithelial ovarian cancer. Cancer Treat Res., 156, 69-85. 